SylWia NowaK-BAJCAR

Uniwersytet Jagielloński

\title{
Języki kryzysu. Patografie w najnowszej literaturze serbskiej
}

$\mathrm{W}$ ostatnim trzydziestoleciu literatura serbska stanęła w obliczu gwałtownych przemian, dokonujących się w życiu społecznym i politycznym. Przypomnijmy, że procesy demokratyzacji stały się w tym kraju możliwe dopiero po 5 października 2000 roku, a nie po roku 1989, jak to miało miejsce w przypadku większości państw bloku socjalistycznego. W okresie, kiedy przed większością z nich otwierała się przestrzeń wolności, historię Serbii w latach dziewięćdziesiątych co kilka lat znaczyły daty w świadomości społecznej odczytywane jako przełomowe. Pierwszą stanowił rok 1991, oznaczający początek bratobójczych wojen, które doprowadziły do rozpadu Socjalistycznej Federacyjnej Republiki Jugosławii, z niezwykle bolesnym dla Serbów wydarzeniem (które skomplikowało stosunki z Zachodem), jakim było bombardowanie przez siły nAто tworzących wówczas jedno państwo Serbii i Czarnogóry. Zabójstwo premiera Zorana Đinđicia w 2003 roku dla wielu oznaczało kres i upadek marzeń o demokratyzacji, czerwiec 2008 roku, kiedy to aresztowano przywódcę bośniackich Serbów, Radovana Karadžicia, w sposób symboliczny oznaczył zaś zmianę polityki serbskiej, odczytaną jako gotowość do rozliczenia się z przeszłością i stosunkiem do minionej wojny, a zarazem jako warunek rozmów z Unią Europejską oraz otwarcie drogi do członkostwa w niej'.

1 W 2009 roku, kiedy Serbia zgłosiła oficjalnie akces do członkostwa w Unii Europejskiej i kiedy wprowadzono dla obywateli tego kraju liberalizację wizową, liczba osób 
Przywołanie tych faktów wydaje się niezbędne dla zrozumienia specyfiki i uwarunkowań literatury serbskiej, na której ta odłożona w czasie tranzycja odcisnęła swój ślad w postaci bardzo silnie ujawniających się ,języków końca”.2. Za ich pomocą serbscy pisarze, stawiając diagnozę obecnej sytuacji jako kryzysowej, jej źródeł upatrywali w przeszłości, odwołując się do (alternatywnych wizji) historii własnego narodu czy tworząc różnorodne futurologiczne projekty, a w ostatnim czasie także utwory poświęcone pandemii (Mihajlovski 2020; Zec 2020). Choć w okresie reżimu Slobodana Miloševicia siła oddziaływania antyzachodniej propagandy była ogromna, a umacniał ją dodatkowo sposób finansowania kultury, dyskryminujący działalność niezależnych podmiotów, powstawało wtedy wiele utworów o ogromnym ładunku subwersyjnym, otwarcie i ostentacyjnie komentujących polityczną rzeczywistość Serbii, ale także rejestrujących rozdarcie, w jakim - za sprawą zbrojnej interwencji państw Zachodu znalazła się antymiloševiciowska opozycja demokratyczna. Jak bowiem można było przewidzieć, efektem ubocznym działań NATo była wzmożona niechęć obywateli Serbii do Stanów Zjednoczonych i krajów zachodnioeuropejskich oraz wzrost nastrojów nacjonalistycznych.

W najnowszej literaturze serbskiej stan świadomości jednostki skonfrontowanej z epokowymi wydarzeniami opisywany był często za pomocą écriture patografique. Ujmując sytuację politycznego i społecznego kryzysu jako stan chorobowy, autorzy publikowanych w ostatnim trzydziestoleciu literackich patografii ${ }^{3}$ poddawali zarazem refleksji pewne tabuizowane zjawiska ( $w$ tym np. AIDs)

opowiadających się za przystąpieniem Serbii do uE była większa niż obecnie (wynosiła 74\%). Co ciekawe, według badań Instytutu Spraw Europejskich (Institut za evropske poslove) - utworzonej w 2010 roku pozarządowej niezależnej i pozapartyjnej organizacji, której celem jest realizacja idei Serbii jako pełnoprawnego członka wspólnoty euroatlantyckiej i promowanie wartości europejskich - pod koniec 2019 roku poparcie to nie przekraczało 50\% (Srbija. Evropska unija... 2020), podczas gdy według danych Ministerstwa Integracji z Unią Europejską (Ministarstvo za evropske integracije) wynosiło ono 54\% (Evropska orijentacija građana... 2019: 5).

2 Określeniem tym posłużył się Przemysław Czapliński, badając ślady przełomu w odniesieniu do polskiej sceny literackiej po 1989 roku. Jak stwierdzał: „Myślenie w kategoriach «końca» podporządkowuje sobie, i za własne narzędzia obiera, metafory schyłku, zmierzchu, kresu, kryzysu, zaniku, choroby, niemocy, umierania, śmierci, wyczerpania" (Czapliński 1997: 23).

3 W celu prezentacji sposobów, w jakie pisarze serbscy odpowiadali na wyzwania epoki, posłużę się narzędziami metodologicznymi wypracowanymi na polskim gruncie przez Iwonę Boruszkowską, która kategorię chorobowego defektu, będącego rodzajem nienormatywności, w swoich badaniach traktuje jako temat i tekstową praktykę. W odróżnieniu od Mateusza Szuberta, który rezerwuje określenie patografii dla tekstów niefikcjonalnych 
jako impuls do refleksji nad zachodzącymi w świecie procesami globalizacji. Określając mianem doświadczeń defektywnych „wszelkie reprezentowane w tekstach kultury doświadczenia związane z przeżywaniem i rozumieniem stanów patologicznych”, które postrzegane są jako „element kondycji egzystencjalnej człowieka znajdującego się w stanach zdrowia i choroby", Iwona Boruszkowska słusznie zauważa, że „przewartościowują one priorytety, zmieniają sposób postrzegania świata, wywołując różnorodne postawy, mobilizują do podjęcia procesów poznawczych" (Boruszkowska 2018: 49, wyróż. - S.N.B.). Te zaś nakierowane są nie tylko na świat psychiki i somatyki samego podmiotu, ale także na zrozumienie wzajemnych relacji pomiędzy nim a rzeczywistością zewnętrzną, która nierzadko staje się zarówno przestrzenią doświadczania choroby, jak i miejscem, które ją generuje, co uniemożliwia ustanowienie źródła patologii. $\mathrm{W}$ odniesieniu do tak wykreowanej przestrzeni odnieść możemy rozważania Boruszkowskiej dotyczące infirmerium. Badaczka stwierdza bowiem:

Można przypuszczać, że występowanie różnych wariantów topofigury infirmerium stanowi, najogólniej mówiąc, świadectwo kryzysu współczesności, komplikacji na linii zdrowie - choroba, jednostka społeczeństwo, ja - inny. Tekst infimeryjny oferuje alternatywny sposób mapowania literatury punktami, w których przebywa podmiot w kryzysie, podmiot defektywny. Nieważne, czy nazwiemy je (za Foucaultem) heterotopiami dewiacji czy miejscami konstytuowania się defektu lub też miejscem (auto)refleksji podmiotu patologicznego - kategoria tekstu infimeryjnego stwarza możliwość rozpoznania zależności między „chorą” (nawet jeżeli „choroba” jest jedynie narzuconą z zewnątrz etykietą) jednostką a miejscem (światem, czasem, przestrzenią) istnienia kondycji ludzkiej i konstytuowania się tożsamości (Boruszkowska 2018: 103).

W omawianych w artykule utworach przestrzenią naznaczoną stygmatyzacją, wyrzuceniem poza nawias jest Serbia. Kulminacyjnym, traumatycznym wydarzeniem w okresie rządów Slobodana Miloševicia były - trwające od 24 marca do 20 czerwca 1999 roku - kontrowersyjne bombardowania, które stały się swoistym probierzem dla proeuropejsko zorientowanej części społeczeństwa.

(Szubert 2019: 29), Boruszkowska w obrębie écriture patografique wyodrębnia strategię abstrakcji, strategię rejestracji oraz strategię dygresji, z których pierwsza i trzecia dotyczą doświadczeń wykreowanych przez twórcę. Strategia abstrakcji odnosi się do chorób wyobrażonych, nieistniejących w żadnej klasyfikacji medycznej, zaś strategia dygresji do chorób sklasyfikowanych (Boruszkowska 2016: 39-41; 2019: 51-52). 
Interwencja wojsk NATO wygenerowała bowiem nastroje poznawczej konsternacji i zagubienia, które w swojej dedykowanej „bohaterom wojny ojczyźnianej 1999 " powieści Pod senkom zmaja (W cieniu latawca) z 2001 roku przejmująco opisał Đorđe Pisarev (ur. 1957). Stan narastającej wojennej psychozy wyraził on za pomocą repertuaru postmodernistycznych chwytów oraz zabiegów uniezwyklania rodem z powieści gotyckiej, horroru i thrillera, dla których eksplicytnie wskazanym przez Pisareva intertekstualnym wzorcem stała się powieść Dokręcanie śruby Henry’ego Jamesa. Jej tytuł jest metaforą sposobu budowania atmosfery grozy i kulminacji napięcia, które w zakończeniu utworu nie zostaje - czego oczekuje czytelnik - rozładowane, lecz przeciwnie, spotęgowane. W powieści serbskiego pisarza dzieje się podobnie, jednak stanu paraliżującego przerażenia - „dokręcania śruby” - nie wywołuje w niej nierozwikłana zagadka nawiedzonego domu, lecz strach przed śmiercią, wywołany zbrojną interwencją krajów sojuszu euroatlantyckiego. Bohaterowi utworu Pisareva, powołanemu do służby wojskowej pisarzowi, przeciwnikowi reżimu zostaje powierzone zadanie obrony obiektów zagrożonych atakami z powietrza. Staje się więc on - wbrew swojej woli - uczestnikiem prowadzonej przez Miloševicia wojny obronnej z Zachodem. Wypowiedź protagonisty, adresowana do pilota bombowca zrzucającego, oprócz ładunków wybuchowych, także pisane łamanym językiem serbskim ulotki propagandowe, streszcza ówczesne nastawienie do zbrojnej interwencji krajów zachodniej demokracji większości serbskiego społeczeństwa i dylemat, w obliczu którego ono stanęło:

Człowieku, najpierw chcesz mnie zabić, a potem proponujesz współpracę! Mój Wódz - mój problem. Dla chłopaka w śmiercionośnej maszynie pancernej [zrzucane materiały - S.N.B.] są znakiem obopólnej nienawiści i pogardy okazanej Przywódcy, który od lat nas prowadzi od jednej przegranej wojny do drugiej. Co do tego jesteśmy zgodni, ale... (Pisarev 2001: 65) ${ }^{4}$.

W dziełach Svetislava Basary (ur. 1953) jedynym możliwym sposobem oddania stanu gwałtownego wzrostu entropii rzeczywistości w Serbii lat dziewięćdziesiątych stał się dyskurs paranoiczny. Strategia tego twórcy zastosowana w powieści Ukleta zemlja (Zaklęty kraj) z 1995 roku, opisującej rzeczywistość państwa rządzonego przez Slobodana Miloševicia, udatnie oddawała sytuację „niekompatybilności” Serbii z innymi krajami. Przy czym nie była to dla

4 Przekładów wszystkich przywołanych fragmentów i tytułów omawianych dzieł pisarzy serbskich dokonała autorka artykułu. Jak dotąd nie zostały one wydane w Polsce. 
Basary strategia nowa, bowiem od początku lat osiemdziesiątych, czyli czasu prozatorskiego debiutu, określała konsekwentnie jego artystyczny idiom, silnie osadzony w duchu Pynchonowskiego absurdu i paranoi ${ }^{5}$. O ile jednak strategie przejęte z nowej prozy amerykańskiej do diagnozowania sytuacji „późnego kapitalizmu” ze względu na specyfikę uwarunkowań polityczno-ekonomicznych Jugosławii lat osiemdziesiątych i jej otwartość na wpływy kulturalne i ekonomiczne Zachodu mogły wydawać się uzasadnione, o tyle trwające od 1991 do 1999 roku wojny towarzyszące rozpadowi SFRJ nie wpisały się w retorykę ponowoczesności i ogłaszanych przez zachodnioeuropejskich myślicieli wszelkich „końców”, w tym końca historii zapowiedzianego przeze Francisa Fukuyamę, który upatrując w demokracji liberalnej ostatecznej fazy rozwoju dziejów, stwierdzał, że „nie będzie już dalszego rozwoju podstawowych zasad oraz społecznych instytucji, wszystkie istotne problemy znajdą bowiem swe ostateczne rozwiązanie" (Fukuyama 1996: 11). Fakt ten wyraziście i za pomocą zjadliwej ironii przedstawił w przywoływanej już wcześniej powieści Pisarev:

Wokół słychać wystrzały, ale dlaczego ja, umundurowany postmodernista, mam się martwić, skoro „nie wierzę w realność”? [...] Serbia, strefa mroku i urzeczywistnionej postmoderny: przestrzeń - co ponad wszelką wątpliwość potwierdziłaby nawet sama Linda Hutcheon, gdyby tylko uczestniczyła w scenach, w których głowa może tak łatwo i zabawnie odlecieć - debaty, cytatu, partyzantki i pojednania. To definitywnie nie jest pastisz, lecz „wyzwalający probierz wyznaczników subiektywności i kreatywności”, produktywne spotkanie ze sztuką (życia) zmiennych punktów widzenia, wielowymiarowej samoświadomości, w sensie lokalnym i globalnym, jednym słowem - urzeczywistniona przestrzeń postmoderny (Pisarev 2001: 40-41).

Stwierdzić więc można, że przypomniane polemicznie przez serbskich prozaików diagnozy były przejawem zagubienia i niemożności odnalezienia w świecie jakichkolwiek punktów oparcia. Sytuację tę określić można mianem kryzysu interpretacyjnego.

Rozpad Jugosławii i szok nim wywołany u pokolenia starszych twórców, których młodość i dojrzałość upłynęła w Socjalistycznej Federacyjnej Republice Jugosławii, przejawiał się w podważaniu statusu ontologicznego rzeczywistości,

5 Przekłady utworów Thomasa Pynchona na język serbski, w tym słynna Entropia (Pynchon 1982: 201-218), ukazały się m.in. w zredagowanej przez Davida Albahariego dwutomowej antologii Savremena svetska priča (Światowe opowiadanie współczesne) z 1982 roku. 
w poczuciu, że ta, w której żyli, była rzeczywistością urojoną. Przyjęty przez nich dyskurs paranoi z jednej strony wyrażał konsternację i niemoc poznawczą, z drugiej zaś strony był świadectwem podejmowanych przez jednostkę prób odnalezienia panującego w świecie ukrytego porządku. Stan choroby psychicznej, oddawany przede wszystkim w sposobie konstruowania świata przedstawionego i w języku wypowiedzi, w którym wielość sprzecznych informacji łączyła się z potrzebą łączenia wszystkiego ze wszystkim, uniemożliwiały ustalenie statusu ontologicznego rzeczywistości, jawiącej się jako symulakrum.

Język paranoi, określany klinicznie w pracach Zygmunta Freuda i Jacquesa Lacana przez dwa symptomy: poczucie bycia prześladowanym i konstrukcję alternatywnego systemu przekonań w celu zneutralizowania opresyjności świata zewnętrznego, opisywał sytuację kryzysu interpretacyjnego jako reakcję podmiotu na niemożność scalenia przez niego elementów rzeczywistości w obliczu dojmującej potrzeby zrozumienia.

Opisany przez teoretyków język psychozy (Jameson 1998: 201-209; 2011: 26-38; Deleuze, Guattari 2017), odniesiony do ponowoczesnej kondycji społeczeństwa postindustrialnego, został przez Svetislava Basarę wykorzystany do opisu nowoczesnej sytuacji Serbii znajdującej się w stanie wojny nie tylko z niedawnymi mieszkańcami wspólnej ojczyzny, połączonymi dotąd więzami „jedności i braterstwa”, ale z całym światem Zachodu. Co prawda w tekstach przywołanych wcześniej myślicieli jest mowa o schizofrenii, która w odróżnieniu od dyskursu paranoi jest typowa dla modernizmu (Haasan 1987: 84-96), ale Bran Nicol, opierając się na rozpoznaniach Teresy Brennan zawartych $\mathrm{w}$ artykule The age of paranoia (Brennan 1991: 20-45), słusznie stwierdza, że choć dyskurs schizofrenii oddający rozszczepienie jaźni jednostki wydaje się lepiej charakteryzować ponowoczesną kondycję człowieka niż dyskurs paranoi, ten drugi pojawia się zarówno w jednej, jak i w drugiej formacji (Nicol 1999: 44-62). Wskazując na kryzys interpretacyjny, wyraża on potrzebę poszukiwania i nadawania sensu, czyli epistemofilii, w wydaniu paranoidalnym przybierającej formy dyskursu scalającego. Ów kryzys w modernizmie zostaje przezwyciężony w akcie interpretacyjnym odbiorcy dzieła, w postmodernizmie wskazuje zaś na niemożność jednoznacznego usensowienia świata i dokonania jego ostatecznego zrozumienia, a więc - na interpretacyjną niemoc. Tak dzieje się zarówno w przypadku utworów Basary, jak i Davida Albahariego czy Pisareva, należących do starszego pokolenia serbskich prozaików, którzy wspólnie z autorami debiutującymi w latach osiemdziesiątych $\mathrm{xx}$ wieku należeli do nurtu określanego wówczas mianem „młodej serbskiej prozy”, później zaś - mianem „prozy postmodernistycznej”. Ich artystyczne gusta w dużej mierze wyznaczał Albahari - anglista, tłumacz i pisarz, znany także polskiemu czytelnikowi z przekładów jego dzieł. 
Serbia, tytułowy „zaklęty kraj”, kryjąca się w utworze Basary pod nazwą Etrasciji ${ }^{6}$, opisywana jest jako produkt chorej wyobraźni jej Prezydenta, „emanacja jego charyzmy, fatamorgana utkana $z$ wizji i pragnienia sprawowania władzy nad wielkim krajem. Widowisko. Wyobrażenie. Projekcja” (Basara 2009: 128), była „tajemniczym państwem na samej granicy prawdopodobieństwa” (Basara 2009: 31) o niesprecyzowanych granicach, wahających się „od 3200 (w wersji realnej) do $850000 \mathrm{~km}^{2}$ w wersji idealistycznej” (Basara 2009: 31), „państwem dotrzymującym kroku najnowszym osiągnięciom fizyki: teorii chaosu, kwarków, cząsteczek, o których nie można powiedzieć na pewno, że istnieją bądź nie, są tu albo tam czy też w obu tych miejscach jednocześnie" (Basara 2009: 64). Wydobycie iluzorycznego sposobu istnienia Serbii, wytwarzanej w różnorodnych dyskursach własnych i obcych, pozwalały Basarze zdemistyfikować narodową mitomanię obecną w serbskiej retoryce nacjonalistycznej, a z drugiej strony odnieść się krytycznie do prowadzonej przez Zachód polityki wobec Serbii, którą tak opisywał powieściowy Prezydent:

Nikt nas nie uznaje, a wszyscy mają tutaj swoje ambasady, dyplomatów, szpiegów, wszyscy nieustannie węszą, monitorują, liczą, kontrolują, nakazują. Idioci. Jakby nie mogli pojąć, że nasze dwie cywilizacje są niekompatybilne. Jak na przykład BASIC i PASCAL. Niczego o nas nie mogą się dowiedzieć, a nas nie interesuje nic, co ich dotyczy. Czego mianowicie mielibyśmy się dowiadywać? Wszystko, co wiedzą o sobie (lub wyobrażają sobie, że wiedzą), zgromadzili w książkach i plikach komputerowych. Smutne kraje bez tajemnic. Państwa, w których każda gospodyni domowa ma prawo się dowiedzieć, czy minister zdradza swoją żonę. Nie, nigdy nawet mi nie przyszło do głowy, że mógłbym żyć w którejś z tych pedantycznych i nudnych demokracji. Mydlą oczy swoim poddanym zapełnionymi witrynami sklepowymi, punktualnymi pociągami, uprzejmym traktowaniem i „prawami człowieka”. Dają góry pieniędzy, by kupowali wszystko, o czym pomyślą. Dzięki temu nie dostrzegają nudy i pustki życia. Etrascija to coś innego. To kraj introwertyczny, państwo apofatyczne (Basara 2009: 63-64).

Wszyscy mnie oskarżają, że prowadzę wojnę. A czy mam wybór to już nikogo nie obchodzi. Sami widzicie, w jakim stanie znajduje się Etrascija. Nadludzkim wysiłkiem utrzymuję całość w ryzach. Imperialiści zagarnęli lasy, rudy miedzi i żelaza, ikony i mszalne kielichy, nawet rzeczywistość. Wszystko to wbudowali w fundamenty swojej

6 Nazwa jest prześmiewczą aluzją do jednej z etnogenetycznych teorii, wywodzących pochodzenie Serbów od Etrusków. 
lichwiarskiej międzynarodówki. W moim kraju ocalały tylko legenda i szczątki folkloru. Dla Erasciji, podobnie zresztą jak i Kraciji, jedyną szansą ocalenia i przetrwania na mapach świata jest bycie w centrum uwagi mediów. A co może wzbudzić większe zainteresowanie niż wojna? Wy prowadzicie ją, by siać zagładę, a my po to, żeby nas nie zgładzono (Basara 2009: 130).

Zastosowana przez Basarę strategia dekonstruowania poprzez zderzanie ze sobą i ośmieszanie dwu perspektyw (wewnętrznej - mitologizującej - i zewnętrznej - orientalizującej), uniemożliwiająca usytuowanie i zdefiniowanie pozycji autora, wyznacza status ontologiczny Serbii jako błędu w systemie, defektu. Dyskurs paranoidalny, za pomocą którego pisarz dezawuuje zarówno mechanizmy rodzimej polityki (oscylującej między aspiracjami do świata Wschodu i Zachodu' ${ }^{7}$, jak i polityczne strategie państw Europy wobec Serbii, urasta w jego twórczości do rangi ogólnej diagnozy rzeczywistości ogarniętej szaleństwem, które sprawia, że główny bohater powieści, dyplomata Zjednoczonego Królestwa, ulega w Etrasciji niespodziewanej przemianie, stając się wielbicielem geniuszu Prezydenta po tym, jak brak kompetentnych służb medycznych zmusza go do przeprowadzenia na sobie samym, zwieńczonego spektakularnym sukcesem, zabiegu usunięcia wyrostka robaczkowego.

Przywołana powieść, obrazująca współczesne relacje Serbii z Zachodem, wpisuje się zresztą w całokształt twórczości Basary, który newralgiczne momenty historii swojego kraju (w tym miejscu warto może przywołać powieść Početak bune na dahije - Początek buntu przeciw dahijom - ośmieszającą narodową mitomanię wybrańczo-cierpiętniczą, problem serbskiego „snu o Europie” i przyczyny wadzenia się Serbów ze światem), jego kultury i polityki przedstawia

7 Jak zauważa Maria Dąbrowska-Partyka, dzieje nowoczesnej kultury serbskiej od XVıII wieku stoją pod znakiem zmieniających się faz „europeizacji” i kultywowania „rdzenności”, których nie należy utożsamiać z „kosmopolityzmem”, „internacjonalizmem” czy „patriotyzmem”. Wiązać je raczej trzeba z próbami określenia przez społeczeństwo patriarchalne własnej tożsamości poprzez próby odnoszenia jej do otoczenia traktowanego jako niedościgły wzorzec bądź jako zagrożenie. W centrum obu koncepcji zawsze jednak pozostawał autostereotyp „narodu-ofiary”, „narodu wybranego”, „sprawiedliwego odwetu”, historii i polityki postrzeganych jako spisek bądź przeznaczenie. Działających współcześnie, zaangażowanych proeuropejsko intelektualistów, jak zauważa Dąbrowska, „określamy jako «proeuropejskich» nie dlatego, że podjęli jakąś kolejną próbę «europeizacji” Serbów i Serbii, ale dlatego, że wyzwolili się z zaczarowanego kręgu zbiorowej krzywdy, zbiorowego losu, zbiorowej odpowiedzialności. Podkreślają znaczenie osobowej perspektywy społecznych działań oraz społeczny sens indywidualnego wyboru moralnego" (Dąbrowska-Partyka 2004: 249-250, wyróż. M.D.P.). 
w kontekście dziejów Europy oraz kluczowych dla niej wydarzeń. Zamachowi w Sarajewie z 1914 roku poświęcona jest np. powieść Anđeo atentata (Anioł zamachu), zaś postaci Ivo Andricia - Andrićeva lestvica užasa (Drabina grozy Ivo Andricia), w której ukazuje zjawisko jugonostalgii jako narzędzie polityczne. Wspólną cechą wszystkich powieści tego pisarza jest obecność czarnego humoru, którego subwersyjność uniemożliwia, wbrew proeuropejskim, a obecnie prounijnym poglądom Basary prezentowanym $\mathrm{w}$ jego eseistyce, felietonach i wywiadach, ustalenie światopoglądowej pozycji autora.

Mechanizm ten, relatywizujący wszelkie kategorie i pojęcia (w tym także kategorie „my” - „oni”, umożliwiające identyfikację z określonym systemem wartości), wykorzystał serbski pisarz w pochodzącej z 2006 roku i nagrodzonej prestiżową nagrodą czasopisma „NIN" antyutopijnej powieści Uspon i pad parkinsonove bolesti (Wzlot i upadek choroby Parkinsona), której tło historyczne stanowią wydarzenia rewolucji październikowej.

Utwór Basary stanowi dokumentację medyczną przebiegu schorzenia Damjana Lavrentievicza Parkinsona, odkrywcy choroby, którą - w powieściowej fikcji - dotknięta jest większa część ludzkiej populacji. Przypadłość ta oddziałuje na procesy zachodzące $\mathrm{w}$ świecie, począwszy od codzienności, przez historię, politykę, religię i sztukę (Basara 2007: 32-33) ${ }^{8}$, jedna zaś z jej mutacji, tzw. parkinsonizm C, wydaje się zdrowiem i ze względu na brak symptomów klinicznych można ją diagnozować jedynie na podstawie patologicznych zachowań, do których należą: uprawianie sportu, dbanie o zdrowie, abstynencja i powstrzymywanie się od używek9.

8 Dokumentacja ta została opracowana przez Pavla Kuzmiča Kasatkina, agenta rosyjskich tajnych służb, który śledzi historyka Vaznesenskiego rekonstruującego życie Damjana Lavrentjeviča Parkinsona. Ten zaś jako pierwszy zdiagnozował tajemniczą chorobę o nazwie morbus parkinsoni. Spostrzeżenie, że działania chorych prowadzą albo do dobrostanu ludzkości, albo do jej degeneracji, doprowadziło do wyodrębnienia różnych jej mutacji, rozpoznawalnych nie w obrazie klinicznym choroby, lecz w zachowaniu chorych. I tak duchowa forma choroby, na którą cierpiał sam Parkinson (parkinsonizm A), za sprawą rozwoju medycyny i udoskonalenia technik eliminacji bólu zmutowała $\mathrm{w}$ formę B, na którą zapadają ludzie słabego ducha o niskim progu wytrzymałości na ból, a przecież „Choroba jest najgroźniejsza, gdy się jej nie odczuwa” (Basara 2007: 33). Późniejsze badania doprowadziły do odkrycia najbardziej niebezpiecznej mutacji, parkinsonizmu C, w którym choroba wydaje się zdrowiem.

9 Na pozór absurdalny wywód dotyczący zdrowego stylu życia, który ma być w powieściowym świecie przejawem parkinsonizmu C, zyskuje inny wymiar, gdy odczytamy go przez pryzmat następującego rozpoznania Mateusza Szuberta: „Współczesna kultura Zachodu ustanawia nowy rejestr grzechów, na którego czele znajduje się niedostateczna dbałość o zdrowie fizyczne i własny wygląd. Całkowicie zmienił się też próg tolerancji 
W dzienniku choroby i momentów ozdrowień powieściowy Parkinson spirytualizuje stan chorobowy. Uznając siebie najpierw za proroka, a następnie ideologa, przedstawia swoją opartą na spiskowych teoriach wizję świata, wskazując na rządzące nim mechanizmy i prawidłowości, jego politycznym celem staje się zaś święta wojna chorych przeciwko zdrowym. Po drugim nagłym ataku choroby $\mathrm{w}$ wiejskiej spelunce doznaje iluminacji - dochodzi do wniosku, że życie jest chorobą, i sam uznaje siebie za proroka, a parkinsonizm za doktrynę religijną:

Moja choroba może zbawić świat. Jeżeli tylko zdołam go zainfekować. Tu i tam, to prawda, z wielkim wysiłkiem, udało mi się zarazić kilka szpitali i miast oraz kilka natchnionych osób, które pod postacią programu politycznego spożytkują tę Chorobę dla dobra swoich narodów. [...] Ale ogólnie rzecz biorąc, poniosłem porażkę. Lekkomyślna i powierzchowna ideologia zdrowia wkrótce zahamuje moją chorobę i skaże świat na przedwczesną śmierć. Co więcej, doprowadzi do usunięcia wszelkich wzmianek o Chorobie Parkinsona (która przetrwa tylko w fikcji). Aby oszustwo uczynić doskonałym, przypisze się ją niejakiemu doktorowi Parkinsonowi, pośledniemu prowincjonalnemu lekarzowi i uzna za zespół objawów, spośród których najbardziej charakterystycznym jest drżenie. Wszystkie one razem wzięte wcale nie są Chorobą w klasycznym ujęciu, lecz tym, co prawosławna tradycja określa mianem słabości (Basara 2007: 70).

Relatywizując kategorie zdrowia i choroby, wydobywając płynność, umowność i arbitralność sposobów określania tych kategorii oraz instrumentalizację, jakiej podlegały one w historii ludzkości, Basara doprowadza do absurdu tezy Michela Foucaulta (Foucault 1987) o wykorzystywaniu kategorii choroby i zdrowia jako narzędzi społecznej i politycznej kontroli (z którymi Basara nota bene się zgadza, co potwierdzają jego wypowiedzi prasowe, dotyczące wykorzystania medycyny do celów ideologicznych w historii zSRR czy nazistowskich Niemiec). Strategia ta wynika ze sceptycyzmu wobec wszelkich poczynań człowieka, które serbski pisarz odczytuje jako skazane na porażkę. Tezę tę zresztą, jak się wydaje,

na zachowania kojarzone z niezdrowym stylem życia: dawne, obarczone ryzykanctwem i spontanicznością posługiwanie się ciałem, tak typowe dla wielu subkultur i ruchów kontestujących mieszczański pragmatyzm, przestało być akceptowane. Armia ekspertów w dziedzinie zdrowia, lekarzy, konsultantów, trenerów, health-coachów, ustanawia nową ewangelię zdrowia, której złamanie lub choćby naruszenie może grozić społeczną ekskluzją" (Szubert 2019: 34-35). 
podtrzymują wszyscy przedstawieni tu twórcy, podejmujący w swoich utworach tematykę relacji Serbii ze światem, także ci, którzy odnoszą się w nich eksplicytnie (o czym w dalszej części tekstu) do problemu akcesu Serbii do Unii Europejskiej.

Dyskursem paranoi posłużył się także Albahari (ur. 1948), pisarz nurtu literatury wyczerpania, w powieści z 2005 roku zatytułowanej Pijavice (Pijawki), która opisuje rzeczywistość Belgradu w 1998 roku w obliczu psychozy wywołanej groźbą bombardowań Serbii przez NATo, widzianą oczyma felietonisty czasopisma „Minut” i wielbiciela miękkich narkotyków. Za pomocą Kabały próbuje on odczytać sens pozostawionych przez kogoś, nieprzypadkowych, jak sądzi, znaków, ponieważ „wszystko posiada jakiś ukryty sens i znaczenie, lecz my nie jesteśmy wystarczająco sprawni, by ten komunikat usłyszeć i zrozumieć” (Albahari 2005: 14).

Powieść łączy elementy polityczno-sensacyjnego thrillera osnutego wokół faktów związanych $\mathrm{z}$ antysemickimi incydentami, które wówczas miały miejsce w Belgradzie, powieści historycznej poświęconej dziejom Zemunu - żydowskiej dzielnicy stolicy Serbii - powieści ezoterycznej oraz romansu. Status ontologiczny kraju, w którym żyje bohater, oraz prezentowanych w dziele wydarzeń podważany jest nieustannie nie tylko w sposób implicytny w wypowiedziach bohatera-narratora: „Nigdy wcześniej rzeczywistość nie była bardziej oddalona od rzeczywistości niż wówczas w Belgradzie i nigdy wcześniej nie było takiej presji, by właśnie tę rzeczywistość uznać za jedynie prawdziwą" (Albahari 2005: 86), ale także przez niemożność ustalenia, czy sposób odczytywania wydarzeń i one same nie są efektem oddziaływania na protagonistę substancji psychoaktywnych (w których szuka ukojenia przed opresyjną rzeczywistością), czyli czy przedstawione fakty nie są wyłącznie odzwierciedleniem stanu świadomości narratora, bowiem „wszyscy biorą środki uspokajające, tabletki na poprawę nastroju i przeciw spadkowi nastroju, jeden mniej czy jeden więcej, to bez znaczenia, szczególnie gdy cały naród leży na wielkiej kozetce psychiatrycznej” (Albahari 2005: 176).

Sytuację, w jakiej znalazła się Serbia, określoną w powieści mianem „wyspy dryfującej z dala od świata niczym kolonia trędowatych, o których nikt już nie chce się martwić” (Albahari 2005: 73), najpełniej oddaje poniższy dialog:

Ci idioci będą nas bombardować [...] i być może nikt $\mathrm{z}$ nas nie ujdzie z życiem. Jacy idioci, zapytałem, Europejczycy czy Amerykanie? I jedni, i drudzy powiedział Marko. Milczeliśmy. Próbowałem wyobrazić sobie bombardowanie i zdołałem jedynie przywołać filmowe obrazy rejestrujące atak aliantów w kwietniu 1941 roku. Widziałem skrzydło samolotu i bomby spadające jak kłody, a potem pilota, który się odwrócił i szeroko 
uśmiechnął. Miał ładne zęby. Słychać było oddech Marka. Głęboki i miarowy jak podczas snu. Smutno jest, odezwał się nagle, gdy nikt cię nie kocha. Nie wiedziałem, co ma na myśli, i skąd nagle miłość, po bombach. Jesteśmy teraz kloaką świata, powiedział, i boję się, że jeszcze długo nią będziemy (Albahari 2005: 107).

Próby odkrycia związków między poszczególnymi elementami rzeczywistości i ustalenia zasad porządkujących chaos za pomocą matematycznych formuł (trójkąt Sierpińskiego, odwołania do Szkoły Brukselskiej belgijskiego fizyka rosyjskiego pochodzenia, Ilyi Prigogine’a, której członkowie twierdzili, że uniwersum nie musi podporządkowywać się drugiej zasadzie termodynamiki, czyli system nie musi ulegać chaosowi i rozpadowi, lecz posiada zdolność do reorganizacji, w innej formie - Albahari 2005: 42) okazują się reprodukcją mechanizmów opresyjnego systemu, w którym tkwi bohater, co wskazuje na niemożność ich przezwyciężenia.

Wspomniane poszukiwania nie prowadzą bowiem do mistycznego poznania, lecz wikłają bohatera w polityczną grę, w której odgrywa on podwójną rolę: ofiary antysemickich ataków i zarazem jej reżysera, który swoimi artykułami podsyca atmosferę nienawiści. Kreując rzeczywistość o niejasnym statusie ontologicznym, odmalowaną jako przywidzenie człowieka odurzonego narkotykami, alkoholem oraz informacjami płynącymi z mediów, zmuszonego przez okoliczności polityczne do podjęcia rozpaczliwych prób zrozumienia i zinterpretowania sytuacji, w jakiej się znalazł, Albahari obnaża mechanizmy manipulacji i działania propagandy. Co więcej, próby wydobycia się z tego stanu jeszcze bardziej wikłają bohatera, prowadząc go do następującej uniwersalnej diagnozy: „Nienawiść jest chorobą, wywołaną przez zaburzenie równowagi niezbędnej do normalnego funkcjonowania jednostek i zbiorowości" (Albahari 2005: 199).

Poczucie beznadziei i niemocy dominuje także w utworach młodszych pisarzy, którzy swój idiom artystyczny opierają na technice realistycznej oraz kategorii jednostkowego doświadczenia. Oni również dla oddania sytuacji kryzysowej posługują się dyskursem choroby, ale ostentacyjne opowiedzenie się po stronie mimetyzmu stanowi dla nich symboliczny gest powrotu do rzeczywistości, przejścia z przestrzeni dyskursywnej do przestrzeni życia, które rozgrywa się tu i teraz. Status ontologiczny tej rzeczywistości nie jest przez nich podważany, podobnie jak wiara w możliwości poznawcze człowieka. Problemy polityczne i społeczne, z którymi zmaga się Serbia, poddane wnikliwej, najczęściej eseistycznej analizie i krytycznemu osądowi, stają się w twórczości realistów tłem losów konkretnych jednostek. Dlatego - w odróżnieniu od postmodernistów, obnażających w swoich utworach mechanizmy zniewalania 
umysłów przez ideologów opętanych szaleńczymi wizjami - młodsi twórcy zwracają się ku opisowi indywidualnych doświadczeń (bólu, cierpienia, niemocy fizycznej i umysłowej), sytuacji ludzi z marginesu, wyobcowanych, odsuniętych, napiętnowanych różnorodnymi defektami, zmagających się z codziennością ułomnego świata. Stan chorobowy staje się w ich utworach uniwersalną metaforą sytuacji egzystencjalnej, w której pogrążony jest człowiek, zaś intymna, odizolowana przestrzeń świata wewnętrznego, przestrzeń szpitala, własnego pokoju, przestrzeń zmagań z chorobą staje się wartościowanym pozytywnie infimerium, które pozwala odciąć się od patologii świata poza nim. Choroba dotkniętych nią jednostek jest stanem doświadczanym i przeżywanym, ale nie powoduje - jak u postmodernistów - kryzysu interpretacyjnego.

Pesymistyczne diagnozy na temat drążących Serbię politycznych i społecznych chorób w twórczości postmodernistów oraz pisarzy młodszego pokolenia nie dotyczą wyłącznie Serbii. Dla obu generacji problemy własnego kraju są egzemplifikacją procesów, mających miejsce na całym świecie. Co znamienne, ocena możliwości wyjścia z zapaści postrzegana jest pesymistycznie nawet wówczas, gdy po upływie niemal dziesięciolecia od zakończenia wojen Serbia staje w obliczu nowych, tematyzowanych przez prozaików wyzwań, jakie stanowi perspektywa członkostwa w Unii Europejskiej. W utworach tych wciąż powraca temat izolacji, odcięcia od świata i jego skutków. Sytuacja wyobcowania, marginalizacji, niemożności nawiązania komunikacji z resztą świata jest wynikiem choroby społecznej, jaką są - według pisarzy - ksenofobia i nacjonalizm, niezmiennie od lat drążące Serbię, ale i inne państwa. Dla twórczości realistów znamienne jest bowiem wskazywanie na własny kraj i złożoność jego historii jako jeden $z$ wielu punktów zapalnych na mapie świata, stawiających co istotne - pod znakiem zapytania utopię „międzykulturowego dialogu” i wszelkich idei wspólnotowych. O ile jednak postmoderniści zatrzymują się na pesymistycznych diagnozach, młodsi twórcy remedium na patologię widzą w powrocie do wartości etycznych. Uznając za źródło wszelkiego zła i problemów współczesnego świata nienawiść, fakt, że - jak stwierdza w swojej powieści Vladimir Arsenijević - „człowiek człowiekowi wilkiem”, drogi przezwyciężenia kryzysu upatrują w budowaniu relacji międzyludzkich opartych na zrozumieniu, szacunku dla ludzkiej godności, uczuć i cierpienia. Przejawia się to m.in. poprzez przyjęcie idiomu „nowej wrażliwości” - języka empatii, której przykład stanowią proza Srđana Valjarevicia (ur. 1967) (zob. Nowak-Bajcar 2018) i powieści Igora Marojevicia, oraz idiomu „nowego brutalizmu”, którego egzemplifikację stanowi powieść Predator Arsenijevicia.

Marojević (ur. 1968) zadebiutował w 1997 roku powieścią Obmana Boga (Zwodzenie Boga) o podtytule „a paranoic fiction” utrzymaną w duchu 
Pynchonowskiego absurdu i prozy jego starszych kolegów. Kolejne powieści tego twórcy odchodzą jednak od tego wzorca, dotykając problemów z powodów społecznych lub politycznych dotąd marginalizowanych czy tabuizowanych, co stało się powodem określania dzieł tego twórcy mianem „snajperskiego realizmu”. Druga powieść Marojevicia zatytułowana Dvadeset i četiri zida (Dwadzieścia cztery ściany) z 1998 roku jest opowieścią o trudnej miłości do osoby chorej, opowieścią o cielesnym wymiarze niedyspozycji, o cierpieniu, niemocy, ale i seksualności chorego. Choroba w powieści Marojevicia staje się znakiem marginalizacji i wykluczenia środowiska osób cierpiących na AIDs (jak dotąd Dvadeset $i$ četiri zida to jedyna powieść serbska poświęcona tej problematyce), których, oprócz schorzenia, łączy stygmatyzacja związana z faktem, że tworzą je opozycjoniści, przeciwnicy Slobodana Miloševicia (akcja rozgrywa się w 1996 roku). Narrator jest dziennikarzem opozycyjnego, finansowanego przez Fundację Sorosa dziennika „Nova zvezdica” (Nowa gwiazdka), którego nazwa i logo (źółta gwiazdka) ma czytelników „inspirować do refleksji o wspólnocie europejskiej” (Marojević 1998: 60). Choroba jego partnerki (której początkowo nie jest świadomy) staje się dla narratora przepustką do świata ludzi wyrzuconych poza nawias, jest rodzajem wtajemniczenia, wprowadzenia do świata uczuć i empatii. Opowiadając historię miłości do osoby zarażonej, bohater przyjmuje postawę biografa-świadka, relacjonującego swoją i cudzą przeszłość, rodzące się i rozwijające uczucie okazuje się zaś procesem poznawania siebie i zarazem drugiego człowieka, procesem prowadzącym do przewartościowania własnego życia. Desperackim i szokującym czytelnika przejawem tych czynności jest celowe zarażenie się narratora AIDs podczas miłosnego aktu. Czyn, który z jednej strony odczytać możemy jako gest autodestrukcyjny, autoagresywny, samobójczy, staje się w powieści symbolicznym (i kontrowersyjnym) przejawem empatii, zjednoczenia, utożsamienia z cierpiącym oraz solidarności z nim w sensie etycznym. Jest rodzajem poznania, które nie narusza autonomii drugiego ${ }^{10}$, a zarazem rodzajem kontestacji świata znajdującego się poza ograniczoną tytułowymi „dwudziestoma czterema ścianami” garsonierą bohatera - rodzajem jego „infimerium”. Ucieczka do „schronu”, „kryjówki” w odizolowany od polityki i opresji świat przestrzeni prywatnej, w świat intymnych przeżyć, uczuć i cierpienia pozwalają w pełni ujawnić się ludzkim uczuciom. Doświadczenia

10 Anna Łebkowska zauważa, że „[...] relacja między poznaniem siebie i poznaniem drugiego zazwyczaj rozpięta jest między dwoma biegunami: między świadomością niepoznawalności, monadyczności a pragnieniem takiego odtwarzania w sobie innego, które nie narusza jego autonomii. [...] Opowiedzieć o innym, nie reifikując go, zachowując jego podmiotowy wymiar - oto jedno z zadań, które stawia przed sobą literatura współczesna, i zarazem jedna z jej w pełni uświadamianych aporii” (Łebkowska 2008: 174). 
graniczne, przeżywanie choroby, obcowanie z nadchodzącą śmiercią, empatyzowanie z cierpiącym pozwalają, według Marojevicia, osiągnąć pełnię człowieczeństwa, wznieść się ponad wszelkie podziały.

Wydaje się zresztą, że taką samą, transgresyjną funkcję ma dla pisarza podejmowanie wszelkich tabuizowanych dotąd przez literaturę serbską tematów ${ }^{11}$, które - podobnie jak bezkompromisowe rozliczanie się z przeszłością Serbii i narodowymi autostereotypami - jest rozpoznawczą sygnaturą jego dzieł (co znamienne, wypowiadając się na temat swoich literackich inspiracji, pisarz wskazuje na twórczość austriackiego pisarza i dramaturga Thomasa Bernharda).

W utworze Roman o pijanstvima (Powieść o pijaństwie) z 2019 roku Marojević w podobnej konwencji kreśli klimat społeczny i polityczny Serbii lat 2009-2014. Powieść jest zapisem zmagań bohatera z chorobą alkoholową, w którą popada po powrocie z kilkuletniego pobytu w Hiszpanii. Rok 2009, w którym rozpoczyna się akcja powieści, oznacza oficjalny początek starań Serbii o członkostwo w Unii Europejskiej. Ich tłem są, w dużej mierze nadal nierozwiązane, wewnętrzne bałkańskie spory, nacjonalistyczne uprzedzenia i historyczne zaszłości Słowenii i Chorwacji - nowych państw we wspólnocie europejskiej oraz kandydującej do niej Serbii, przywoływane przez autora z ironicznym dystansem. Historię rodzinnego kraju bohatera i jego życiowych doświadczeń symbolicznie określa tytuł - Saga o depresiji (Saga o depresji) - przygotowywanej przez niego powieści, o czytelnikach której jej wydawca, opierając się na „korzystnych statystykach Europejskiego Kolegium Neurofarmakologii w Serbii sądzi, że będą stanowili liczną grupę docelową" (Marojević 2019: 193).

Na takim politycznym tle narrator-pisarz przedstawia swoje podróże po Europie i Ameryce Południowej oraz stopniowe popadanie w chorobę alkoholową i nieudaną walkę z nią (temu procesowi na planie światopoglądowym odpowiada przemiana opozycjonisty w nacjonalistę) oraz jej konsekwencjami, m.in. impotencją:

Nie byłem bożyszczem kobiet, nawet wówczas gdy konkurencja była mocniejsza, ale większość tutejszych mężczyzn aktualnie nie tylko żyła w niedostatku, przez co utraciła pewność siebie, ale także odczuwała skutki traumatycznych lat dziewięćdziesiątych i długo tłumionych

11 Powieść Marojevicia Šnit (Wykrój) z 2007 roku opowiada o skomplikowanych narodowościowych relacjach Serbów, Chorwatów i Niemców w Zemunie, obecnie dzielnicy Belgradu, w czasach Niezależnego Państwa Chorwackiego, Parter (Parter) z 2009 roku tematyzuje impotencję, powieść Majčina ruka (Matczyna ręka) z 2011 dotyczy tzw. naddunajskich Szwabów, zaś Ostaci sveta (Szczątki świata) z 2020 roku podejmuje temat obozu koncentracyjnego w Jasenovcu. 
urazów. Ich wybuchy pod postacią różnych przypadłości odczuwali nawet ci, którzy do tej pory z premedytacją traumatyzowali innych. Sześcioletni pobyt w Barcelonie przynajmniej częściowo uwolnił mnie od nich albo je wyciszył. Z powodu nieszczęść wielu zmagało się z różnymi dolegliwościami, na przykład impotencją, która i mi się zdarzała. Trudno jest zachować męskość społecznemu skazańcowi (a to stanowiło tylko mniej istotną część mojego problemu). Wydaje się, że w Serbii nadal więcej jest kobiet, którym udało się ocalić kobiecość, niż mężczyzn o nienadszarpniętej męskości (Marojević 2019: 161).

Impotencja staje się w powieści Marojevicia defektem, który symbolicznie oddaje stan serbskiego społeczeństwa w zmaganiach z kwestią możliwego akcesu do Unii Europejskiej. Problematyzowanie miejsca Serbii w Europie jest przewodnim motywem utworu, powracającym ironicznie w prezentowanych w powieści publicznych debatach oraz codziennych rozmowach, jak np. przywołana poniżej, w której - podczas badań okresowych - lekarz konstatuje świetny stan zdrowia pacjenta będącego w trakcie terapii odwykowej i notorycznie łamiącego jej zasady:

- Nieprawdopodobne! - [lekarz - S.N.B.] w dobrym nastroju wrócił za biurko, zdjął stetoskop i rozłożył ramiona. - Niech Pan mi zdradzi sekret pozytywnej reakcji psychosomatycznej, która stanowi jedyną możliwą przyczynę niedającej się w sposób logiczny uzasadnić poprawy Pańskiego zdrowia. Niewątpliwie mamy tu do czynienia z czynnikiem psychologicznym, nagłym ustąpieniem stresu albo uwolnieniem się od lęku, który jest zmorą nas, Europejczyków.

- Serbia nie jest w Unii Europejskiej - powiedziałem, a lekarz przytomnie się roześmiał, jakby nigdy w życiu nie słyszał nic głupszego (Marojević 2019: 219).

Także konferencje, jak ta zorganizowana na chorwackiej wyspie Brač w żartobliwie wybranej miejscowości Bol (której nazwa w tłumaczeniu na język polski oznacza „ból”), stoją pod znakiem bolesnych powrotów do przeszłości, tej dalszej i tej nieodległej, oraz poczucia niemożności przezwyciężenia konfliktów i impasu wszelkiego dialogu:

Temat konferencji był polityczny: w jakiejś zaadaptowanej grocie, w samym środku przestrzeni wypełnionej publicznością, uczestnicy pochodzący z państw niebędących członkami uE opowiadali się za przystąpieniem swoich krajów do niej, podczas gdy pozostali trzej byli 
zdecydowanie za wystąpieniem Słowenii z UE, tak jak niedawno przyjętej do niej Chorwacji. Kiza próbował przezwyciężyć kryzys dialogu, stwierdzając, że wierzy w pojednanie Chorwatów i Serbów. Powiedział, że musimy sobie wybaczyć po dwa wielkie błędy historyczne i ponownie się pokochać. Mówiąc o serbskich błędach, za które musimy przeprosić, a oni je zrozumieć, zebrał największe brawa tego wieczoru. Pierwszy rekord padł, gdy mówił o tym, jak Puniša Račić strzelał do pięciu chorwackich deputowanych w Parlamencie Królestwa Serbów, Chorwatów i Słoweńców w 1928 roku, a w kolejnym roku król Karađorđević ogłosił dyktaturę, co doprowadziło do definitywnego fiaska dialogu między dwoma narodami i do utworzenia Chorwackiej Organizacji Rewolucyjnej Ustaszy. Był to zaledwie wstęp do wystąpienia Kizy. Gdy stwierdził, że obecność Jugosłowiańskiej Armii Ludowej w Chorwacji od jesieni 1991 roku do lata 1995 roku była naruszeniem konstytucji, wydało mi się, że grota eksploduje od oklasków. - A teraz kolej na was - powiedział Kiza i publiczność ucichła. - Musicie uznać Jasenovac i przestać relatywizować zbrodnie na Serbach w Niezależnym Państwie Chorwackim. My zaś powinniśmy wam to wybaczyć - powiedział, na co rozległy się skąpe brawa, które zamarły po kolejnym słowie. - Burza ${ }^{12} \ldots$ - zdołał jedynie powiedzieć, a skonfudowana publiczność zaczęła szemrać. Na pytanie, które padło $\mathrm{z}$ audytorium, Kiza nie chciał odpowiedzieć. Ja w każdym razie starałem się mówić jak najmniej ze względu na zaburzenia dykcji spowodowane nadmiernym spożyciem. Zachowawczo milczałem, w przeciwieństwie do Rozmana ${ }^{13}$ - Burza to typowy przykład czystek etnicznych. Teraz wszyscy zgodnie powiedzcie: „Przepraszam, Serbowie!” - zaczął jak Laibach, po czym czknął. Spora część zgromadzonych przyglądała się Rozmanowi z obrzydzeniem i niemą, zimną nienawiścią: Słowenia i Chorwacja toczyły zawzięty spór terytorialny i zapewne dlatego miejscowi powściągali się, myśląc, że uda im się uniknąć skandalu dyplomatycznego. Wypowiedź Rozmana była tak nieoczekiwana, że Kiza i ja zaśmialiśmy się po pijacku głośno. Zwrócone na nas spojrzenia pełne były nienawiści (Marojević 2019: 126-127).

Burza (Operacija Oluja) - kontrowersyjna, przeprowadzona w sierpniu 1995 roku przez chorwackie wojsko operacja militarna, której celem było odbicie Krajiny, prowincji zamieszkałej w większości przez Serbów, a kontrolowanej przez samozwańczą Republikę Serbską Krajinę. Akcja ta jest odmiennie postrzegana przez Chorwatów, którzy uważają ją za wyzwolenie okupowanych terenów, i przez Serbów, traktujących ją jako zbrodnię wojenną.

13 Rozman jest Słoweńcem. 
Sytuacja Serbii, pogrążonej w niemożliwych do przezwyciężenia problemach, niemoc wysiłków, które pozwoliłyby na zmianę realiów, nie jest jednak wyjątkowa, lecz stanowi znak czasów, symptom problemów o charakterze globalnym. Liczne związane z działalnością literacką podróże bohatera pozwalają tę sytuację zdiagnozować. Obserwacja zaostrzającego się kryzysu katalońskiego, który ma miejsce w czasie pobytu bohatera w Barcelonie, wywołuje w nim refleksję dotyczącą analogii między wydarzeniami rozgrywającymi się w Hiszpanii a procesami prowadzącymi do rozpadu Socjalistycznej Federacyjnej Republiki Jugosławii poprzedzonego bratobójczą wojną.

Podobne rozpoznania dotyczące sytuacji na świecie pojawiają się w zbiorze opowiadań Predator (2008) Arsenijevicia (ur. 1965). W jego młodzieńczych utworach: debiutanckiej powieści U potpalublju (1994, Pod pokładem) oraz jej kontynuacji Andela (1997, Aniela) antywojenne nastawienie autora i niezgoda na społeczno-polityczną rzeczywistość Serbii wyrażały się w potrzebie ucieczki w sferę życia intymnego i rodzinnego. Choć w zbiorze Predator pacyfizm nadal bardzo wyraźnie się uwidacznia, Arsenijević odchodzi od problemów jednostkowych, wkraczając w krąg zagadnień społecznych i politycznych o charakterze międzynarodowym, globalnym. Tytułowym potworem jest, co zaskakujące, kurdyjski uciekinier z Iraku - kanibal, który w finałowym opowiadaniu morduje i zjada swoją dobrowolną ofiarę - cierpiącego na worarefilię słynnego na całym świecie amerykańskiego podróżnika, Jamesa Rice’a. Jego zaburzenie, polegające na fantazjowaniu o byciu zjedzonym, rodzi się w dzieciństwie przypadającym na lata pięćdziesiąte i sześćdziesiąte $\mathrm{xx}$ wieku i staje się znakiem stanu społeczeństwa zmierzającego do samozniszczenia za sprawą wzrastającego konsumpcjonizmu (por. Bartolovich 1998) oraz ekspansywnej polityki militarystycznej. Choć diagnoza dotyczy przede wszystkim krajów Europy Zachodniej (krytykując jej agresję polityczną, autor nie oszczędza także Serbii), wydaje się, że w swoim zbiorze Arsenijević wyraźnie piętnuje także mocarstwową politykę Stanów Zjednoczonych. Na tle usytuowanych w nieodległej przeszłości wydarzeń, będących egzemplifikacją strategii militarystycznych (iracki atak chemiczny na kurdyjskie miasto Halabdża w 1988 roku, operacja Pustynna Burza przeprowadzona w 1991 roku przez siły koalicyjne państw sprzeciwiających się aneksji Kuwejtu przez Irak, z wiodącą rolą Us A, czystki etniczne dokonywane przez Serbów w Kosowie, oblężenie Sarajewa (1992-1996), atak NATO na Serbię i Czarnogórę, brutalne akcje niemieckiej policji pacyfikującej mieszkańców berlińskiego squadu), prezentowane są historie wywodzących się z różnych środowisk ludzi wykorzenionych: emigrantów, uciekinierów, społecznych odszczepieńców, korzystających z pomocy jednego z ośrodków dla uchodźców w Danii. 
W przedstawionych przez Arsenijevicia historiach nie ma bohaterów jednoznacznie dobrych i złych, każda ze stron konfliktu ma zaś swoje racje i - co istotne - używa przemocy. Figurą tej niejednoznaczności i zmienności ról ofiary i oprawcy, kolonizowanego i kolonizatora jest wspomniany Nihil Bakri, Kurd - ludożerca, w którym po traumatycznych doświadczeniach dzieciństwa, torturach, jakich doświadczał jako chłopiec z powodu politycznego zaangażowania ojca w walkę o prawa Kurdów, zachodzi symboliczna przemiana w wojownika - nacjonalistę. Poprzedza ją mord oraz konsumpcja kilkuletniego chłopca Musy - towarzysza wędrówki Nihila po ucieczce z Halabdży. Jego kolejną metamorfozę, tym razem w typowego przedstawiciela cywilizacji Zachodu, świadomego korzeni i walczącego o prawa swojego narodu, symbolicznie znaczy zabicie i zjedzenie Amerykanina światowej sławy, a przy tym konesera jedzenia - Jamesa Rice’a.

Kanibal pojawia się zatem jako symbol upostaciowanej żarłoczności „nowego człowieka”, który - niezależnie od tego, czy jest oprawcą czy ofiarą - staje się bestią realizującą swoje nienasycone żądze i wykorzystującą przemoc jako środek zapewniający nie tylko dominację, ale i przetrwanie.

W zaprezentowanych narracjach chorobowych - patografiach serbskich twórców należących do różnych generacji i wykorzystujących różnorodne strategie artystyczne - uwidacznia się duża doza sceptycyzmu wobec wszelkich idei wspólnotowych. Nie jest to jednak wyraz osobistego stosunku autorów do kwestii integracji Serbii z Unią Europejską, lecz raczej smutna refleksja nad ograniczonymi możliwościami i niegotowością ich kraju do tego procesu, będącymi wynikiem trudnej sytuacji społeczno-politycznej, złożonych uwarunkowań oraz trudnych doświadczeń historycznych, które do niej doprowadziły. Kryzys, którego metaforą staje się choroba, dotyka - w ocenie zaprezentowanych autorów - nie tylko samej Serbii, lecz całego świata. Podczas gdy postmoderniści (Albahari, Basara, Pisarev), diagnozując niemożność zrozumienia tego stanu jako szaleństwo własne i świata, nie wskazują możliwości wydobycia się z niego, młodsi twórcy - realiści (Valjarević, Arsenijević, Marojević) dokonują krytycznej oceny eksploatacyjnej polityki siłowych rozstrzygnięć, wiodących do pogłębiania i zaogniania problemów. Poddając refleksji kondycję człowieka, w powrocie do świata wartości podstawowych, intymnych upatrują możliwości niwelowania barier, wznoszenia się ponad podziałami, jednoczenia i „europeizacji”. 


\section{| Bibliografia}

Albahari David (2005), Pijavice, Stubovi kulture, Beograd.

Arsenijević Vladimir (2008), Predator, Samizdat B92, Beograd.

Bartolovich Crystal (1998), Consumerism, or the cultural logic of late cannibalism, w: Cannibalism and the Colonial World, red. Francis Barker, Peter Hulme,

Margaret Iversen, Cambridge University Press, Cambridge, s. 204-281.

Basara Svetislav (2007), Uspon i pad Parkinsonove bolesti, Dereta, Beograd.

Basara Svetislav (2009), Ukleta zemlja, Laguna, Beograd.

Boruszkowska Iwona (2016), Defekty. Literackie auto/pato/grafie - szkice,

Wydawnictwo Uniwersytetu Jagiellońskiego, Kraków.

Boruszkowska Iwona (2018), Sygnatury choroby. Literatura defektu w ukraińskim modernizmie, Instytut Badań Literackich PAN, Warszawa.

Boruszkowska Iwona (2019), Écriture patografique, w: Fragmenty dyskursu maladycznego, red. Maciej Ganczar, Ireneusz Gielata, Monika Ładoń, Fundacja Terytoria Książki, Gdańsk, s. 36-52.

Brennan Teresa (1991), The Age of Paranoia, „Paragraph”, nr 1, s. 20-45.

Czapliński Przemysław (1997), Ślady przełomu. O prozie polskiej 1976-1996, Wydawnictwo Literackie, Kraków.

Dąbrowska-Partyka Maria (2004), Orientacja proeuropejska we współczesnej myśli narodowej Serbów i Chorwatów w: taż, Literatura pogranicza. Pogranicza literatury, Wydawnictwo Uniwersytetu Jagiellońskiego, Kraków, s. 249-258.

Deleuze Gilles, Guattari Felix (2017), Anty-Edyp. Kapitalizm i schizofrenia, przeł. Tomasz Kaszubski, Wydawnictwo Krytyki Politycznej, Warszawa.

Evropska orijentacija građana Srbije. Ispitivanje javnog mnjenja (decembar 2019. godine) (2019), https://tinyurl.com/s9zfv5jk [dostęp: 20.04.2021].

Foucault Michel (1987), Historia szaleństwa w dobie klasycyzmu, przeł. Helena Kęszycka, Państwowy Instytut Wydawniczy, Warszawa.

Fukuyama Francis (1996), Koniec historii, przeł. Tomasz Bieroń, Marek Wichrowski, Zysk i S-ka Wydawnictwo, Poznań.

Haasan Ihab (1987), Toward the concept of postmoderism w: tenże, The postmodern turn: essays in postmodern theory and culture, Ohio State University Press, Columbus, s. 84-96.

James Henry (2016), Dokręcanie śruby, przeł. Jacek Dehnel, Wydawnictwo wAB, Warszawa.

Jameson Fredric (1998), Postmodernizm i społeczeństwo konsumpcyjne, przeł. Przemysław Czapliński w: Postmodernizm. Antologia przekładów, red. Ryszard Nycz, Wydawnictwo Baran i Suszczyński, Kraków, s. 190-213.

Jameson Fredric (2011), Postmodernizm czyli logika kulturowa późnego kapitalizmu, przeł. Maciej Płaza, Wydawnictwo Uniwersytetu Jagiellońskiego, Kraków. 
Łebkowska Anna (2008), Poznawanie siebie i poznawanie innego w: taż, Empatia. O literackich narracjach przełomu Xx $i$ XxI wieku, Universitas, Kraków, s. $165-187$.

Marojević Igor (1997), Obmana Boga: a paranoic fiction, Stubovi kulture, Beograd.

Marojević Igor (1998), Dvadeset četiri zida, Stubovi kulture, Beograd. Marojević Igor (2019), Roman o pijanstvima, Laguna, Beograd.

Mihajlovski Stefan (2020), 14 dana karantina, Kreativna knjiga, Beograd.

Nicol Bran (1999), Reading Paranoia: Paranoia, Epistemophilia and Postmodern Crisis of Interpretation, „Literature and Psychology”, nr1\&2, s. 44-62.

Nowak-Bajcar Sylwia (2018), Czy pisarz jest darmozjadem czyli o społecznych pożytkach nicnierobienia. Proza Srđana Valjarevicia, „Porównania”, t. 23, s. $75-89$.

Pynchon Thomas (1982), Entropija, przeł. David Albahari w: Savremena srpska priča, t. 2, red. David Albahari, Prosveta, Beograd, s. 201-218.

Pisarev Đorđe (2001), Pod senkom zmaja, Stylos, Novi Sad.

Srbija. Evropska unija i pregovori: Kakvo je stanje EU integracija na kraju godine pandemie (2020), „Danas”, 8471, https://tinyurl.com/3azzu6tp [dostęp: 21.10.2021].

Szubert Mateusz (2019), Dyskurs maladyczny - perspektywy badawcze, w: Fragmenty dyskursu maladycznego, red. Maciej Ganczar, Ireneusz Gielata, Monika Ładoń, Fundacja Terytoria Książki, Gdańsk, s. 17-35.

Zec Petar (2020), Karantin udvoje, NNk Internacional, Beograd.

\section{| Abstrakt}

Sylwia NowaK-BAJCAR

Języki kryzysu. Patografie w najnowszej literaturze serbskiej

W artykule przedstawiono powstałe w ostatnim trzydziestoleciu wybrane utwory serbskich twórców (David Albahari, Svetislav Basara, Đorđe Pisarev, Igor Marojević, Vladimir Arsenijević), podejmujących problem relacji Serbii z Europą, w tym kwestię wstąpienia tego kraju do Unii Europejskiej. Kluczem interpretacyjnym do analizy tego problemu stała się kategoria choroby będąca metaforą kryzysu dotykającego nie tylko Serbię, ale - w opinii autorów należących do różnych generacji - cały świat. Sceptycyzm uwidaczniający się w dziełach prezentowanych pisarzy nie jest wyrazem osobistego stosunku tych autorów do kwestii integracji Serbii z Unią Europejską, lecz raczej smutną refleksją nad niegotowością ich kraju 
do tego procesu, będącą wynikiem złożonej sytuacji społeczno-politycznej oraz trudnych doświadczeń historycznych, które do niej doprowadziły.

Słowa kluczowe: współczesna proza serbska; patografie; Serbia; Europa; kryzys i jego literackie języki

\section{| Abstract}

SYLWIA NowAK-BAJCAR

\section{The Languages of the Crisis: Pathographies in the Latest Serbian Literature}

The article presents selected works by Serbian prose writers (David Albahari, Svetislav Basara, Đorđe Pisarev, Igor Marojević, Vladimir Arsenijević) created in the last three decades, dealing with the problem of Serbia's relations with Europe, including the issue of this country's accession to the European Union. The interpretative key to the analysis of this problem is the category of disease, which is a metaphor for the crisis affecting not only Serbia, but-in the opinion of authors belonging to different generations-the whole world. The skepticism manifested in the works of the presented writers is not an expression of the authors' personal attitude to the issue of Serbia's integration with the European Union, but rather a sad reflection on their country's unpreparedness for this process, resulting from the complex socio-political situation and difficult historical experiences that led to it.

Keywords: contemporary Serbian prose; pathographies; Serbia; Europe; crisis and its literary languages

\section{| Biogram}

Sylwia Nowak-Bajcar - prof. uJ, dr hab., absolwentka serbistyki i kroatystyki w Instytucie Filologii Słowiańskiej Uniwersytetu Jagiellońskiego, gdzie pracuje od 1995 roku. Jej zainteresowania naukowe skupiają się wokół śladów historii w literaturze i kulturze (szczególnie w literaturach postjugosłowiańskich xx i xxI wieku). Jest autorką artykułów o tematyce literaturoznawczej i kulturoznawczej, tekstów krytycznoliterackich, przekładów oraz książek: Monolog jako światopogląd. Proza Slobodana Selenicia (2001), Mapy czasu. Serbska proza postmodernistyczna wobec wyzwań epoki (2010), Helena, kobieta, której nie ma i która jest. Krakowska biografia Ivo Andricia (2013).

E-mail: s.nowak-bajcar@uj.edu.pl

ORCID: 0000-0002-1537-6268 